\title{
Achieving Sustainable Development Goals in Bangladesh: Does Population Density Matter?
}

\author{
Hafiza Khatun, Nazmoon Nahar Sumiya and Al-Artat-Bin-Ali \\ Department of Geography and Environment, University of Dhaka, Dhaka-1000, Bangladesh \\ Manuscript received: 15 October 2020; accepted for publication: 12 January 2021
}

\begin{abstract}
Bangladesh, one of the most densely populated countries in the world with a density of about 1,265 persons per $\mathrm{km}^{2}$ having a limited land area with high development potential. Being able to accomplish noteworthy achievements in MDGs, Bangladesh is heading towards achieving the targets of the SDGs amid several challenges like high population, resource constraints, poverty etc. This study aims at addressing the challenges and prospect of increasing population density in achieving the SDGs. An exploratory approach has been applied to address how the density of population might influence the achievement of the SDGs. Data on population and other relevant parameters have been identified from census, published documents and articles. The current progress of SDGs attainment shows some of the goals are on track, but more progress could have been achieved unless being hindered by the high density of population. Feeding and providing the basic amenities to this huge population is quite a big challenge with limited resources, in contrast, optimum utilization of the demographic dividend by ensuring effective participation of the young active population in the current development process can also expedite the progress of attainment of SDGs. The adversities of the high density of population can essentially be offset by redistribution of urban population and decentralization of economic activities from major cities. Alongside appropriate and precise policy measures, comprehensive study on quantifying how the density of population is affecting the attainment of SDGs is recommended.
\end{abstract}

Keywords: Sustainable Development Goals, Population density, Challenges, Demographic Dividend, Bangladesh

\section{INTRODUCTION}

Despite differences between countries in all aspects, several unanimous efforts have been taken to ensure prosperity and development across the world. The formulation of Millennium Development Goals (MDGs) in 2000 was such an effort to tackle the indignity of poverty by 2015 (UNDP, 2020). Implementation of MDGs had made an overall improvement in extreme poverty, child and maternal health, and access to water and sanitation. However, the targets of MDGs were not fully achieved and later being influenced by the legacy of MDGs and incorporating new ideas to meet the urgent global environmental, political, and economic challenges, Sustainable Development Goals (SDGs) were adopted in 2015 which is broadly known as "Transforming Our World: The 2030 Agenda for Sustainable Development" (Sachs, 2012; Hák et al., 2016; Ashraf et al., 2019; Swain, 2018). This declaration of SDGs was a remarkable achievement to be able to provide an inclusive and universal set of goals for ensuring global

Corresponding author: Nazmoon Nahar Sumiya

E-mail: sumiya.geoenv@du.ac.bd

DOI: https://doi.org/10.3329/dujees.v8i2.54834 sustainability and human development (Stafford-Smith et al., 2017; Swain, 2018). To achieve decent lives for all on a healthy planet by 2030, the SDGs include 17 goals with 169 different targets, focusing on fighting poverty, reducing inequality, and addressing climate change, while leaving nobody behind (Hák et.al, 2016). These also include goals such as quality education for all, gender equality, and reduced child mortality, which all are directly and indirectly linked with population growth (Abel et al., 2016). Population growth is an important factor of development as it has a direct relationship with resource bases (Kopnina and Washington, 2016). Although the high global population is a challenge to tackle, this vital issue has not explicitly been addressed in the SDGs (Abel et al., 2016). Besides, the growth rate and density of population are not similar across the world and much variation is seen between developed and developing countries (Van Bavel, 2013) and so the attainment of SDGs might be challenging for some countries especially for the developing and underdeveloped ones. Nevertheless, the high population does not necessarily impose problem only, also provide opportunities for sustainable development (UNFPA, 2013).

Bangladesh showed satisfactory progress to meet several targets of MDGs (UNDP, 2020) and is now focusing on the successful implementation of SDGs. 
Being a small country located in the GangesBrahmaputra-Meghna (GBM) delta with a population of more than 166.50 million (BBS, 2019), Bangladesh accommodates about $2.11 \%$ of the world population (Worldometer, 2021). It is having steady economic development with 7.9\% GDP growth in 2019 (Katekar et al., 2020) and about to become a middle-income country by 2021 . Since independence, it has gone through several challenges like high population growth, extreme poverty, food crisis (Sobhan, 2017) along with devastating effects of major disasters like flood, cyclone, drought, landslide etc. Despite these adversities, Bangladesh has managed to overcome the challenges by increasing economic growth, notable progress in crop, fish, and livestock production (Roy et.al, 2019), considerable progress in poverty reduction, gender equality, and several other indicators of socioeconomic development (Hasnath, 2020).

Being a signatory of Agenda 2030, Bangladesh has adopted the SDGs in national planning and the government has taken several initiatives that have brought some visible progress but there are still some sectors that need special attention. The combination of high disaster events as well as increasing human vulnerability resulting from demographic pressure, poverty, social inequality, and coupled with the apprehended climate change indicate that Bangladesh is at high risk to large scale disasters with consequent impact on life and livelihood of the people. It is argued that the direct annual cost to the national economy of natural disasters over the last 10 years (damage and loss of production) was estimated to be between $0.5 \%$ and $1 \%$ of GDP in 2010 (GED, 2020a). In addition to natural disasters, high population is another issue that needs to be taken into consideration prior to any development plan. Since 2000, the annual population growth rate is declining from $3.00 \%$ in 1979 to $1.00 \%$ in 2017 (Chowdhury and Hossain, 2018) but the total population is still quite high. Though there is no such formula to assert straightforwardly that having more or less population determines the development status of a country but certainly, the ratio of population to land or more specifically to resources is crucial to ensure sustained development. Alongside high population, Bangladesh has one of the highest densities of population (Chowdhury and Hossain, 2018) that ranks $10^{\text {th }}$ among the countries of the world (Statista, 2020). In Dhaka city, Chattogram city and some other big cities of the country, the density is very high that indicates the uneven distribution of population (Swapan et al., 2017). Disparities in resources, population, and economy are visible between urban and rural areas of Bangladesh (Hasnath, 2020) and these inter-regional inequalities might influence sustainable development. There is also a rapid increase of the global urban population (Chaterjee et al., 2016) it is also expected that being a fast-growing developing country, the number of people living in urban areas of Bangladesh will also be increased and the challenge of sustainable development might be higher. In such context, this paper focuses on explaining how the high density of population of Bangladesh might influence the achievement of SDGs.

\section{AIMS AND OBJECTIVES}

The aim of this study is to identify to what extent the increasing population density and high population might influence the accomplishment of SDGs. Specific objectives include identifying the challenges, the trend, and pattern of population density, and evaluating how the density pattern influences in achieving the goals of the SDGs.

\section{MATERIALS AND METHODS}

This study has followed an exploratory research design and the data for this study have been collected from various secondary sources mostly from the population census of 2001, 2011, reports from national and international organizations, books, journals, and relevant articles. With the help of Scopus, Web of Science, and Google Search Engine, relevant literatures have been collected on population growth, population density, public health, civic facilities, gender and inequality, education and employment, urban and rural environment, innovation and development, peace and partnership and sustainable development scenario of Bangladesh. Projected population density, population dynamics, and trends of Bangladesh for different periods (after 2011) have been estimated from the publications of the Bangladesh Bureau of Statistics (BBS) and General Economic Division (GED). As the major focus of this paper is on population density, the density of population for 2021 and 2031 have been calculated from the projected population available in the Population Monograph, 2015 published by BBS. Later, based on the density, the challenges and prospects of attainment of SDGs have been identified. To make the discussion concise and coherent, the 17 
goals have been discussed as eight groups by grouping up similar types of goals (Table 1).

Table 1: Thematic Categorization of the SDGs

\begin{tabular}{|l|l|}
\hline Theme & SDGs \\
\hline \multirow{3}{*}{ Poverty and Hunger } & $\begin{array}{l}\text { SDG 1: No Poverty } \\
\text { SDG 2: Zero Hunger } \\
\text { SDG 12: Responsible } \\
\text { Consumption and Production }\end{array}$ \\
\hline Health and Well-being & $\begin{array}{l}\text { SDG 3: Good Health and Well- } \\
\text { being }\end{array}$ \\
\hline Education and & SDG 4: Quality Education \\
Employment & $\begin{array}{l}\text { SDG 8: Decent Work and } \\
\text { Economic Growth }\end{array}$ \\
\hline Gender and Inequality & $\begin{array}{l}\text { SDG 5: Gender Equality } \\
\text { SDG 10: Reduced Inequalities }\end{array}$ \\
\hline Civic Amenities & $\begin{array}{l}\text { SDG 6: Clean Water and } \\
\text { Sanitation }\end{array}$ \\
& $\begin{array}{l}\text { SDG 7: Affordable and Clean } \\
\text { Energy }\end{array}$ \\
\hline $\begin{array}{l}\text { Cities and } \\
\text { Environment }\end{array}$ & $\begin{array}{l}\text { SDG 11: Sustainable Cities and } \\
\text { Communities } \\
\text { SDG 13: Climate Action }\end{array}$ \\
& $\begin{array}{l}\text { SDG 14: Life Below Water } \\
\text { SDG 15: Life on Land }\end{array}$ \\
\hline Innovation and & $\begin{array}{l}\text { SDG 9: Industry, Innovation, and } \\
\text { Infrastructure }\end{array}$ \\
\hline Pevelopment & $\begin{array}{l}\text { SDG 16: Peace, Justice and } \\
\text { Strong Institutions } \\
\text { SDG 17: Partnerships for the } \\
\text { Goals }\end{array}$ \\
\hline
\end{tabular}

Source: Categorized by the authors based on the goals of SDGs.

\section{FINDINGS AND DISCUSSION}

\section{Population Characteristics of Bangladesh Population Density}

Bangladesh is one of the top 10 countries having a higher population density across the world (Statista, 2020). As per the Population Census of 2011, Bangladesh had a total population of 149.8 million with 976 persons living in per $\mathrm{km}^{2}$ having a marked variation in regional distribution. The density of population has been seen increasing significantly with a density of 1,239 and 1,265 persons per $\mathrm{km}^{2}$ in 2018 and 2020 respectively (World Bank, 2020 and Worldometers, 2020). Although there has been an observable decline in the annual growth rate of population especially from the year 2000 , whereas the density of population is increasing steadily (Figure 1) and is projected to be increased till 2050.

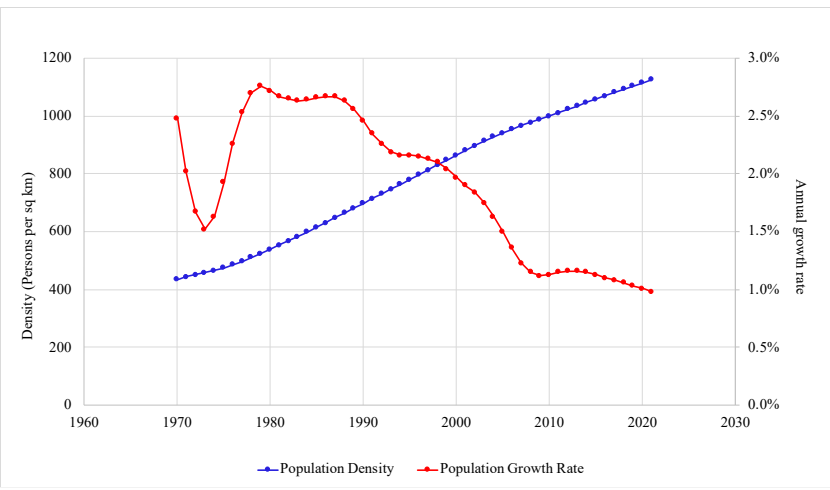

Figure 1: Population Density and Population Growth Rate of Bangladesh (1970 -2020)

Source: Prepared based on Macrotrends (2020)

The population density map of Bangladesh (Figure 2a) based on the 2011 census depicts that Dhaka District, including the Capital, had the highest population density $\left(8,229\right.$ persons per $\left.\mathrm{km}^{2}\right)$ followed by Narayanganj district $\left(4,308\right.$ persons per $\left.\mathrm{km}^{2}\right)$ which had half of the density of Dhaka. On the other hand, the lowest density of population was in Bandarban (87 persons per $\mathrm{km}^{2}$ ) followed by Rangamati (97 persons per $\mathrm{km}^{2}$ ) districts. The physical conditions of these two districts limit the density of the population there. Other 4 districts had a population density of less than 500 persons per $\mathrm{km}^{2}$. In addition to this, population density is higher in the districts located near and surrounding Dhaka.

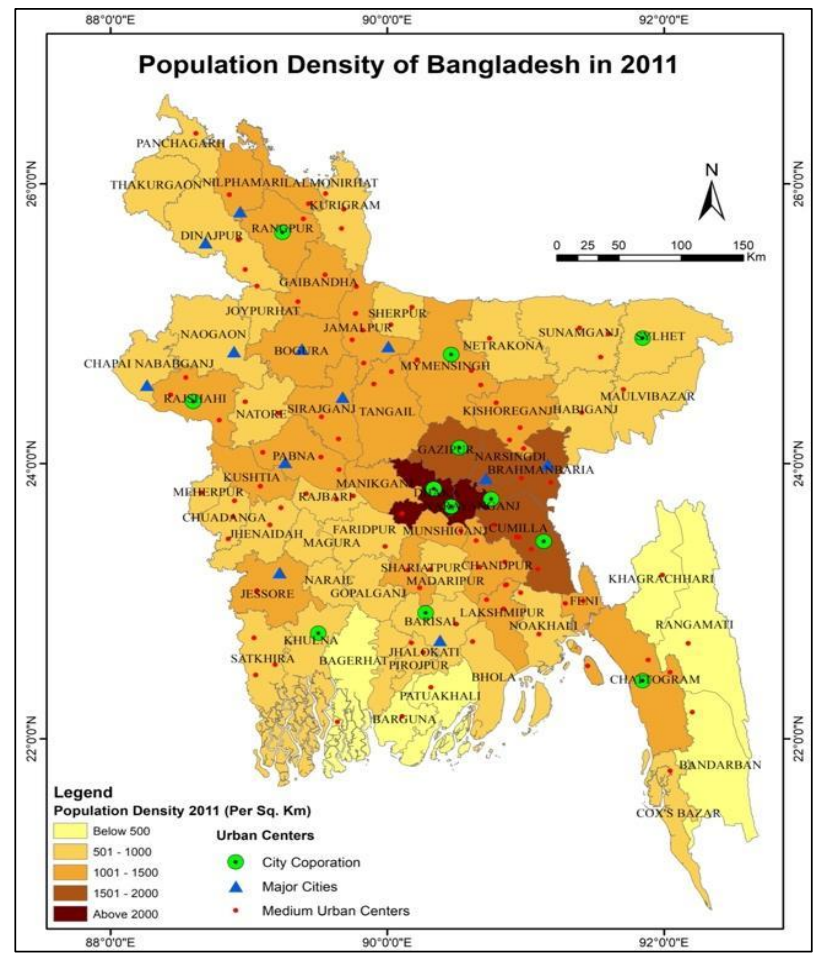

(a) 


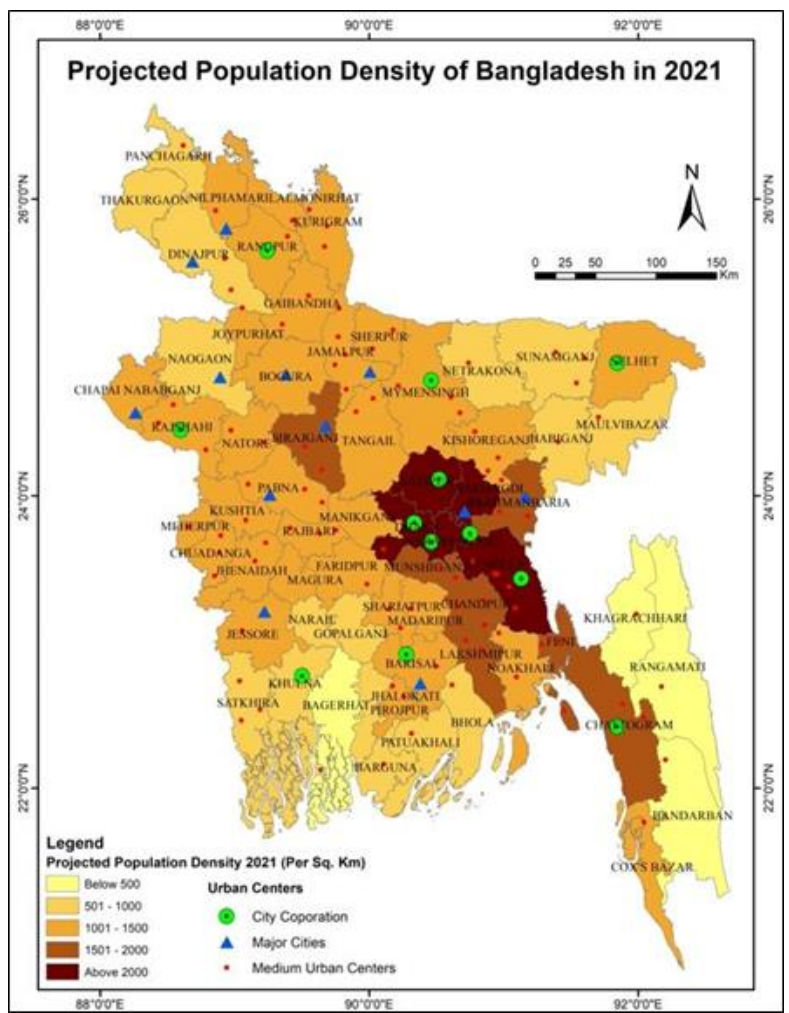

(b)

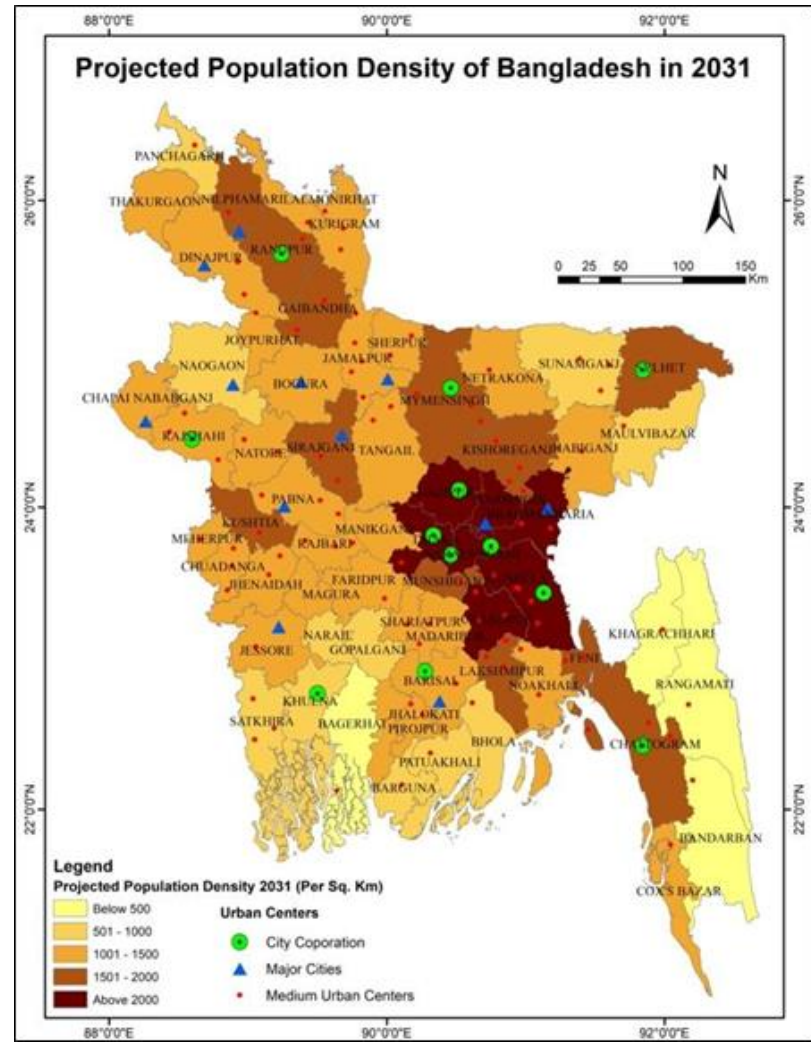

(c)

The projected population density for the year 2021 and 2031 show that the number of districts with a population density of more than 2,000 persons per $\mathrm{km}^{2}$ will be increased from 2 districts in 2011 to 5 in 2021 and 7 in 2031 . All these districts with a projected high density of population are located between Dhaka and Chattogram. Dhaka district being the most populated, the density of population is also projected to be the highest 9,387 persons per $\mathrm{km}^{2}$ in 2021 and 10,053 persons per $\mathrm{km}^{2}$ in 2031(Figure 2). In addition to this, the districts with proximity to Dhaka and Chattogram contain a high density of population and that is projected to increase in 2021 and 2031. While the big cities are already overly populated, the number of districts with a projected density of more than 1,000 persons per $\mathrm{km}^{2}$ is also predicted to be increased from 27 in 2011 to 44 in 2021 and 49 in 2031 (Figure 2).

\section{Demographic Dividend}

Along with the large population size and declining growth rate, the demographic dividend is being visible in Bangladesh. The demographic dividend is the economic growth potential that results from having the proportion of the working age population (15 to 64 years) higher than the dependent population (14 and younger, and 65 and older) (UNFPA, 2014; UNFPA, 2020). There is a constant decline in the annual growth rate of population that is resulting in an increase of the young population than the dependent population (Abusaleh, 2017). Considering the UNFPA's definition of working-age group (15 to 64 years), about $61 \%$ people in 2011 were in working age group, and in 2021 and 2031, the percentage is projected to be $68 \%$ and $69 \%$ respectively (Figure 3 ).

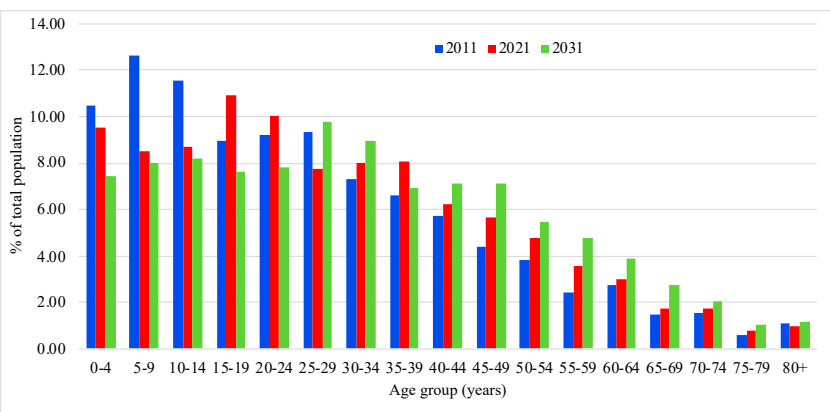

Figure 3: Age Group Distribution of Population in 2011 (census), 2021 and 2031 (projected)

Source: BBS, 2011 and BBS, 2015

Figure 2: Population Density of Bangladesh in (a) 2011, (b) 2021 and (c) 2031 
The youth population aged between 18 to 35 years has increased from past and in 2017 it was about 33\% of the total population (MoYS, 2017). There has also been a significant increase in median age from 20.69 years in 2001 to 22 years in 2011 (BBS, 2011) and in 2020 it is estimated to be 27.6 years (Worldometer, 2020). The average life expectancy has also significantly improved from 57.98 years in 1990 to 72.72 years in 2020 (Macrotrends, 2020). Therefore, despite the lower growth rate, the population will remain high for the next couple of decades, and so the number of aged populations will also be increased.

\section{Urban Population and Urban-Rural Migration}

It is predicted that by 2050 , majority $(60 \%)$ of the population in the lower-middle income countries will live in urban areas (UN and DOESA, 2019), therefore inevitably the rate of urbanization and urban population density is expected to increase in Bangladesh also (Akash et al., 2018). There has been a significant increase in urban population in Bangladesh from $23.3 \%$ in 2011 (BBS, 2011) to $39.4 \%$ in 2020 (Worldometer, 2020). Dhaka being the $11^{\text {th }}$ largest urban agglomeration in the world (UNFPA, 2015), the density of the urban population will be the highest here followed by the other major cities of Bangladesh like Chattogram, Sylhet, Khulna. In addition to natural increase, internal migration is considered as major trigger for increasing urban population density in big cities (UNFPA, 2016; Akash et al., 2018). Besides, displacement due to development activities also pushes people to migrate to other cities (Zaman and Khatun, 2017). Currently, more than 60 percent of the total urban population is concentrated mainly in four metropolitan cities: Dhaka, Chattogram, Khulna, and Rajshahi (GED, 2020b). Natural calamity, and search for work push people to migrate elsewhere mostly to big cities (Khatun et al., 2021). Employment and better living opportunities are the major pull factors for migration in these cities (UNFPA, 2016). The formal and informal employment opportunities in these big cities are created mostly by the presence of high number of industries (Figure 4). Therefore, administrative and strategic location, natural opportunities such as better physiographic conditions, privileged to be less affected by natural hazards compared to other parts of the country also facilitate high population density in Dhaka and its surrounding districts and extend towards the southeast up to Chattogram, followed by
Mymensingh and Sirajganj in the north and west and Sylhet in the northeast (Khatun, 2020) (Figure 2).

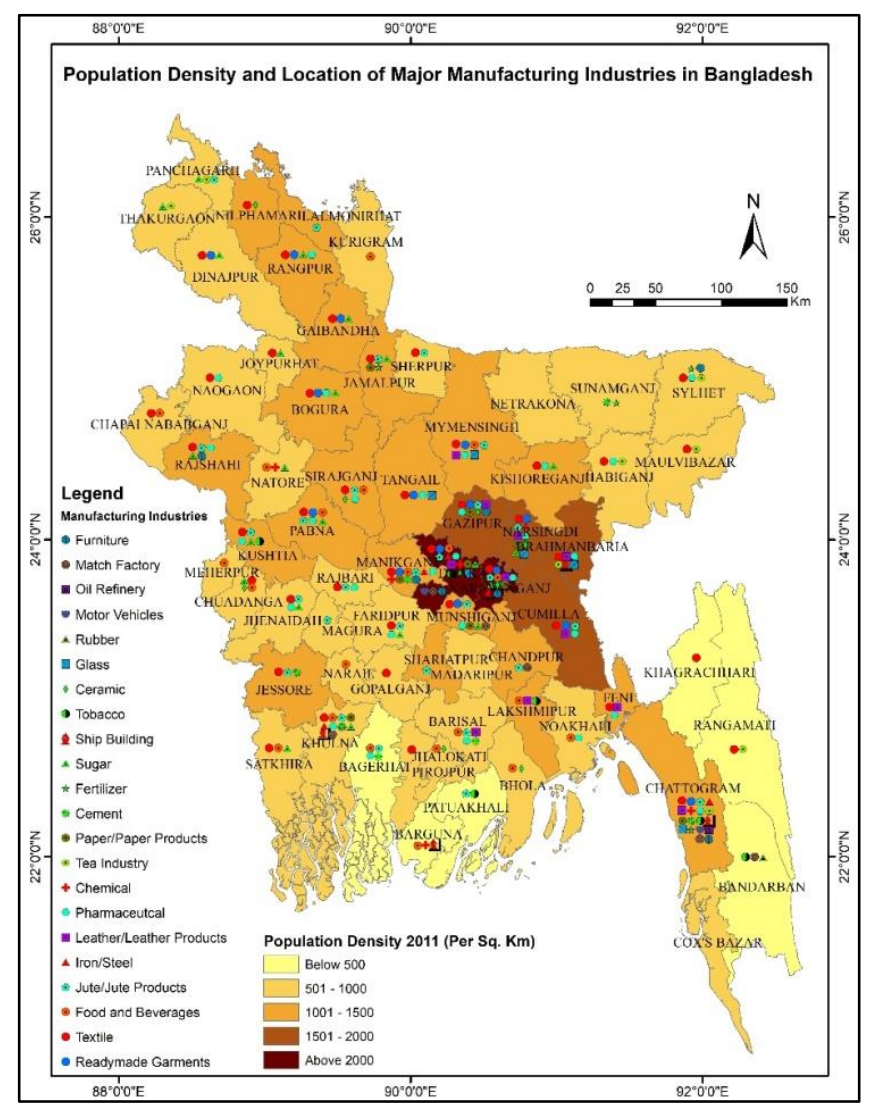

Figure 4: Major Manufacturing Industries of Bangladesh

Source: BBS, 2011; Islam and Nazem, 2017

\section{Sustainable Development Goals in Bangladesh}

\section{Population, Poverty and Hunger}

Feeding a huge population with small land area and very small per capita arable land of 0.049 hectares per person (World Bank, 2020) is undoubtedly a challenging task. The decline in cultivable land is directly linked with the population growth of the country as the lands are being converted for habitation purposes (Karim et al., 2020). Despite gradual decline in agricultural land at the rate of $1.3 \%$ per year (Nazem, 2018), there has been much improvement in rice production (Roy et al., 2019) and overall food production that has stimulated national economic development. The growth of the national economy with increased food production helped in the reduction of poverty headcount, where the extreme poor population declined from $12.9 \%$ in 2016 to $10.5 \%$ in 2019 (GED, 2020b) that keeps Bangladesh on the track to achieve SDG 1 and SDG 2 . 
Since the beginning till 2011, most of the people were employed in primary economic activities such as agriculture (BBS, 2011). The dependence on agricultural activities has started to change, as in 2019, the service sector employed more population (40.1\%) than the agricultural sector $(38.2 \%)$ while the share of the population working in the industrial sector increased rather slowly (GED, 2020a). Still the number of people involved in agricultural activity is quite high, about 24 million people in 2018 (BBS, 2018) and in the context of the frequent occurrence of natural disasters, there is a risk of losing livelihoods. This might increase the poverty level and eventually tend to foster rural to urban migration.

Being known as a disaster-prone country, the food production sector always remains vulnerable that has been evident by the occurrence of flash flood in the north-eastern haor region in 2017 (Sumiya et al., 2019; Abedin and Khatun 2019). Apart from natural calamities, any type of disruption in food production can increase the poverty level. In the light of the present pandemic situation, almost all sectors of employment have been affected due to Covid-19 in 2020-21. The Ministry of Finance (MoF) predicted the budget deficit of FY 2020-2021 to be 6\% of the GDP due to this current pandemic (MoF, 2020). Alongside, a significant portion of the young population $(29.8 \%)$ is not in education, employment, or training as per the estimates of 2017 (GED, 2020a). Researchers have estimated about 20 million (Islam and Jahangir, 2020; Riaz, 2020) people have been temporarily unemployed and pushed back to poverty due to the COVID-19 crisis (Hossain, 2021). Therefore, the significant increase in incidental poverty might affect the stride of attainment of SDG 1 and SDG 2.

Poverty eradication has been a priority target of the Government of Bangladesh (GoB), that led to initiate Social Safety Net programmes for poverty alleviation by targeting the extreme poor, women in poverty, landless people, and other disadvantaged groups (Khuda, 2011). In addition to several stipend schemes, the government is implementing the "Ashrayan Project" since 1997 and has rehabilitated about 320 thousand families with new homes (Daily Star, 2021). All these efforts brought about effective improvement towards lowering the poverty level. In continuation to this success, GoB has taken several measures and policies including National Social Security Strategy (NSSS) in 2015 during the $7^{\text {th }}$ Five-
Year Plan but those action plans have not been executed at an expected rate (GED, 2020a). Regardless of government effort, the increase of population is a threat to the development pathway. On top of that, the projected change in demographic dividend and increase in life expectancy will result in more numbers of the dependent population in the impending future as an aftermath of the high proportion of the young population at present (Figure $3)$.

\section{Population and Health}

In terms of child (under five) mortality rates, there has been a significant improvement in both infant mortality rate (about 21/1000 live births) and neonatal mortality rate (15/1000 live births) from 1972 to 2019 (Figure 5) that already has achieved the target of 2020 (GED, 2020b). There has been an overall improvement in the maternal mortality rate from 318 per 100,000 live births in 2000 to 165 per 100,000 live births in 2019 (GED, 2020b). In terms of general health care facilities, there is massive inadequacy that might have been triggered by increasing number of populations. The number of physicians is significantly lower as there are only 6.73 registered physicians and only 3.3 hospital beds per 10,000 population available as per the estimates of 2019 (DGHS, 2020). Without taking vigorous action to increase healthcare facilities, this gap of physicians-patients will be increasing in coming days with more increase in population density. On top of that the healthcare facilities are concentrated mostly in urban areas than rural areas (Al-Zaman, 2020) and in 2011, the highest (about $34 \%$ ) number of all types of secondary and tertiary medical facilities were distributed within Dhaka division followed by Chattogram division (DGHS, 2012). High density of urban population provides higher threshold population that has resulted in centralized distribution of healthcare facilities in big cities only. In addition to this, considering the demographic dividend with the predicted increase in dependent population and climate change threat, there might be prevalence of diseases in the country in the coming decades (Mondal, 2019). In response to the improvement in health care facilities the government of Bangladesh is planning to implement the $4^{\text {th }}$ Health, Population and Nutrition Sector Programme (HPNSP) by 2030 to achieve health, population, and nutrition sector targets of Bangladesh and SDG 3 (GED, 2020b). Though policy measures are being taken, the 
government expenditure on Health, Population, and Nutrition (HPN) sector is stagnant $(0.7 \%$ of the GDP) for a long time (GED, 2020a).

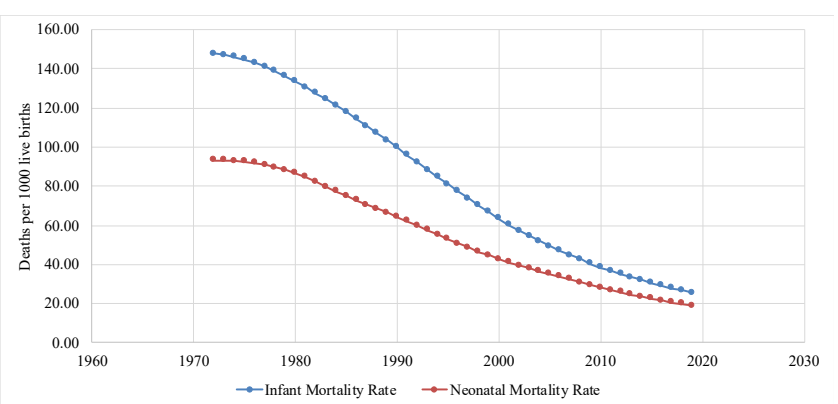

Figure 5: Infant Mortality and Neonatal Mortality in Bangladesh from 1972-2019

Source: UNICEF, 2020

\section{Population, Education and Employment}

There has been a substantial increase in the adult literacy rate from $53.5 \%$ in 2005 to $73.9 \%$ in 2018 (GED, 2020b). In the last decades, more emphasis was given on education sectors especially on female education by taking initiatives (like giving incentives, allowance, scholarships) that reflect on a steady increase in the female literacy rate (Salahuddin et al., 2014). All these efforts have been effectual as in 2017 the youth literacy rate (15-24 years) was higher for women $(94.4 \%)$ than men (91.5\%) (BBS, 2019). The gross enrolment rate of girls in primary and secondary education were also higher than boys (BBS, 2019) where the Gender Parity Index (GPI) for secondary education was 1.19 in 2019 (GED, 2020b). However, in terms of tertiary education still the rate of participation of boys is higher than girls (GPI for tertiary education in 0.93) (GED, 2020b). On top of that, alongside achieving the target of quality education, ensuring quality work for the active population especially for the youth is also crucial. The unemployment rate as per 2019 estimated $4.9 \%$ with about $30 \%$ of the working-age population aged between 15-24 years is not in education, employment, or training (NEET), is a threat that these educated populations are not being utilized properly (GED, $2020 \mathrm{~b}$ ). Another concern is that, with the increase of literacy rate, the unemployment rate of educated youth is also increasing. In fact, the relationship between unemployment and education has become positive and about $13.4 \%$ of young educated people were unemployed in 2018 that supports the statement (BBS, 2018).
Several initiatives have been taken including promoting ICT-based learning countrywide and policy to ensure universal access to good education, and effective implementation of these policies might promote the attainment of SDG 4. Additionally, to expedite the general economic growth and increasing employment opportunities, 98 economic zones are going to be established (BEZA, 2021). Most of the planned private economic zones are clustered within and surrounding the capital and in nearby big cities with high density of population whereas the government economic zones are quite evenly distributed with more concentration in Chattogram division (Figure 6). The implementation of these economic zones will not only create larger employment opportunities but also might affect the present density pattern of the country by reducing urban-ward migration.

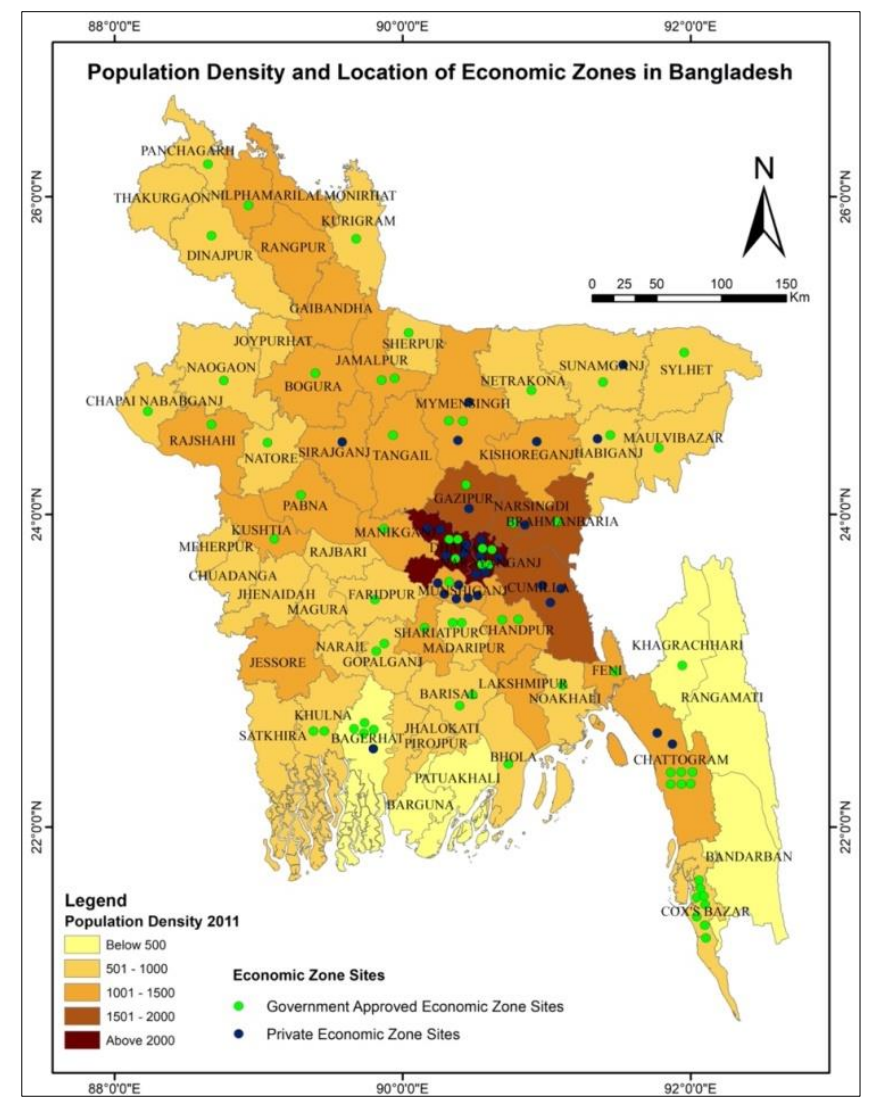

Figure 6: Proposed Economic Zones of Bangladesh

Source: Prepared based on BEZA (2021)

\section{Population, Gender and Inequality}

There has been a visible increase in women's participation in economic activities but still there remain inequalities in terms of the employment sector 
and wages (Hayes and Jones, 2015). Majority of the working women (both in urban and rural) are employed in the informal sector than formal sectors. In urban areas, the highest employment sector for women is the industrial work which can be related to the major employment opportunity in the Ready-made Garments (RMG) sector. Until 2012, there were about 4 million women employed in the RMG sector (Hayes and Jones, 2015) but in recent couple of years, the participation of female labourers has decreased in this sector mostly due to the transformation from labour intensive to automated process (GED, 2020a). While in urban areas female labourers are of young aged (below 35 years), in rural areas females, aged more than 35 years are more likely to participate in labour force (Majumder and Dey, 2020). In the context of wages, there remains inequality till date and so the average monthly income of women is much lower than men in almost all sectors (BBS, 2019). Overall, Bangladesh ranked 141 out of 153 countries in the Global Gender Gap Index 2020 (GED, 2020b). This statistic is not very satisfactory, but some action plans have been taken to improve the condition. Alongside disparities in socio-economic context, girls fall victim to the curse of early marriage and Bangladesh scored the second highest child marriage rate in the world with $74 \%$ of women (aged between $20-49$ years) were married before age 18 (Buchmann et al., 2017). The Ministry for Women and Children Affairs introduced the National Plan of Action (NPA) to end child marriage which was launched in August 2018. The goal of NPA was to lessen the rate of child marriage of girls aged 18 years by one-third in 2021, and to eliminate child marriage by 2041 (BBS and UNICEF, 2017). In addition to this, to empower rural ultra-poor women and improve their lives and livelihoods, the "Strengthening Women's Ability for Productive New Opportunities" (SWAPNO) - social transfer project has been undertaken and is still ongoing since 2014 (GED, 2020a). Though measures to minimize genderbased violence have undertaken there has been an increase in domestic violence due to the current pandemic situation (Reza, 2021). Hence, not only financial security is important but ensuring social safety is also important to ensure gender equality and the SDG 5.

While talking about inequalities, resource inequality also accompanies gender inequality. Globally the rich-poor disparity is at its highest. In
Bangladesh, resource inequalities are visible at regional level, polarized in big two cities (Hasnath, 2020) and at personal or household level (Titumir, 2021). The estimates of 2016 show that the poorest $10 \%$ household population received $1.01 \%$ of the national income whereas the richest $10 \%$ population owned $38.16 \%$ of the national income (BBS, 2018).

\section{Population and Civic Facilities}

The estimates of 2019 show that nationally $84.6 \%$ households have access to improved sanitation facilities (GED, 2020a) while the number is slightly higher in the urban areas than in rural areas. In the case of water, nationally $85.17 \%$ households have access to clean drinking water (BBS, 2019) and in terms of safely managed drinking water the number is $47.9 \%$ only (GED, 2020b). With continued increase of population and booming population density in urban areas, ensuring access to sustainable and clean sources of drinking water supply and sewage system can be a challenge (Siddiqy, 2017) that might affect achieving the targets of SDG 6.

Nationally $92.23 \%$ households have access to electricity in 2019 but only $3.25 \%$ of the total energy consumption is from renewable energy sources (GED, 2020b). Ensuring access to clean and affordable energy is a big challenge ahead along with the pressure of overpopulation (Katekar et al. 2020).

\section{Population, Cities and Environment}

It has been mentioned earlier that the big cities are overly crowded with population. Dhaka, the capital city is projected to be the $6^{\text {th }}$ largest megalopolis of the world by 2030 (Bashar and Fung, 2020). High population pressure is currently affecting the quality of life in the major cities. With the increasing number of migrants, there is an obvious increase in the slum population as well as excessive demands for civic facilities. An estimate of UN-Habitat shows that about $55.1 \%$ of the urban population of Bangladesh lived in slums in 2014 (GED, 2020b). This high density of population eventually results in subsequent deterioration of the urban environment. Alongside, the agglomeration of industries in and around the big cities produces pollutants in return that affects the air, water, and soil quality of urban areas (Hakeem, 2017). The discharge of wastes and pollutants to the surrounding rivers and waterbodies in urban areas is polluting the water (Sarkar et al., 2019) and also the 
groundwater aquifers ultimately affecting the water ecosystem adversely (Hasan et al., 2019; Bashar and Fung, 2020). The pollution in rivers affect the oceans and therefore, as an obvious consequence pollution is increasing in the Bay of Bengal. All these pollutions are ultimately affecting the marine ecosystem by degrading the species and their habitats (Akash et al., 2018). Alongside, the increase of population, urbanization and environmental pollution is disturbing the land ecosystem (Khatun, 2000, Akash et al., 2018). Therefore, both in direct and indirect ways the environment is being affected that is a concern to keep pace with the fulfilment of SDG 11 and 14. On top of this, climate change is also going to be another threat not only for the environment but also for development. It is predicted that climate change will proliferate the intensity and occurrence of natural disasters (MoFA, 2018). Besides, the rise of sea level might stimulate displacement (both seasonal and permanent) of a huge number of people from the coastal districts of Bangladesh (Ayeb-Karlsson, 2016; Rakib et al. 2018; Siddiqui and Hossain, 2019). These will add extra pressure to the cities as the destination of the migrants will be the big cities.

\section{Population, Innovation and Development}

Labour market both in home and abroad is an important pillar of the current development process. In such context, to attain the SDG 9, there is no alternative to trained and skilled manpower. Therefore, the advantage of having a high percentage of the working population (working population is 65\%) (Financial Express, 2020), there is much potential to utilize these resources in innovative works. The demand for skilled labour is predicted to increase whereas there remains a skill gap in the agrofood sector followed by the RMG sector (BIDS, 2017). In addition to this, there is a predicted skill gap in IT sectors, construction and engineering sectors, healthcare, leather goods sectors etc. (BIDS, 2016). Therefore, training up people is essential, and this could be attained by incorporating more people in vocational education. Apart from the labour market, innovation is being patronized country-wide, and GoB has initiated the innovation fund under the "Access to Information" (a2i) project (A2I, 2020) that will contribute to innovation-based development in the long run.

\section{Population, Partnership and Peace}

In this competitive world of development, the partnership is crucial in achieving discernible development. To sustain the development progress of Bangladesh, the Public Private Partnership Authority was established in 2010. In the last couple of years, several large-scale development projects like DhakaElevated Expressway, Bangabandhu Hi-Tech City, Economic Zone etc. have been initiated (PPPO, 2021). In addition to this, several other mega projects like Ruppur Nuclear Power Plant, Rampal Coal Power Plant, Matarbari Power Plant, Karnaphuli Underwater Tunnel are also ongoing (Databd, 2020). All these megaprojects are being funded and implemented by international collaboration that is a great example of global partnership. Apart from this, Bangladesh is well known for its contribution in UN peacekeeping missions and 5,255 members of the Bangladesh Army, 345 of Bangladesh Navy, 582 of Bangladesh Air Force, and 654 members of Bangladesh Police are currently deployed in different missions, and of them, 246 are female officials as of September 2020 (Dhaka Tribune, 2020). In addition to international trade deals and collaborative development efforts, these missions are contributing to maintain global peace, security, and development (Zaman and Biswas, 2017).

\section{Discussion}

World population is facing a rapid growth where $15,00,000$ people are being added per week (Population Centre, 2021) and by 2023 the global population is expected to reach 8 billion. This massive population with high rate of growth is and will be a challenge especially for the developing countries to deal with the poverty, hunger, water and energy resource management and environmental degradation issues (Walker, 2015). Bangladesh is already supporting a very high population compared to its land area and the uneven distribution of population has resulted in high density of population in the big cities. Consequently, the pattern of development and distribution of civic facilities are also centralized in the major cities. This loops back to validate the reason behind of high density in the urban areas as it attracts more people by providing employment and other civic amenities. The projected population density pattern based on the current scenario also suggest that these imbalanced distributions will further be persistent. 
The evident outcome of high density of population within a small area is gradual decline in agricultural land due to its conversion to other uses (Ahmad et al., 2005). Therefore, feeding a very high population will be a challenge for the coming days for Bangladesh with a very small arable land per person. In addition to this, the rate of conversion of agricultural lands into other uses is higher in Dhaka, Chattogram, Khulna and Rajshahi cities and in the surroundings where urban area and urban population densities are higher (Hasan et al., 2013). The predicted population density profile shows that there will be 7 more districts where the density will be more than 2000 person per $\mathrm{km}^{2}$ and about $75 \%$ of the total districts will have a density more than 1000 people per $\mathrm{km}^{2}$ (Figure 2). Therefore, immense pressure is anticipated to be imposed on ensuring the basic needs and civic amenities for all living in these densely populated areas. Eventually, supply of water, energy and sanitation facilities will be arduous. Already some of the cities and some regions are facing freshwater crisis due to alarming decline in groundwater level due to the increase of groundwaterbased irrigation and excessive extraction of groundwater for regular use (Sumiya and Khatun, 2016). On top of that, higher the population, bigger the consumption and waste generation. In major cities, the high density of population creates greater waste burden and only $50 \%$ of those wastes are collected and dumped into landfill areas (Pradhan and Kaeser, 2019). Whereas the rest pollute the land, water, and overall environment. In general, the high density of population has tremendous impact on environment (Hakeem, 2017). Moreover, growing concern about environmental degradation in the context of climate change scenario is one of the biggest challenges to tackle. The consequent effects of climate change might also disrupt economic development and may create more population burden to the big cities due to migration and eventually will intensify the population density. Therefore, this vicious cycle of high density and development disparity will persist unless effective policies are not taken.

\section{CONCLUSION AND RECOMMENDATION}

Being one of the most densely populated countries in the world, and having different socio-economic vulnerabilities aided with multifarious natural and anthropogenic disasters, Bangladesh might face a challenge to go forward and achieve the SDGs.
Palpably, there has been a substantial economic development despite adversities of resource constrain and natural disasters. The rate of development and economic progresses are not even across the country that creates regional disparities. The density of population is higher in urban areas than rural areas where the highest in the capital followed by in the big cities and this pattern is predicted to be further intensified.

With continued economic development, poverty alleviation efforts have seen some success but still a big portion of people are living below the poverty line. Despite anthropogenic pressure pushing the availability of cultivable lands, crop production especially rice production has increased. Besides, sufficiency in fish and livestock production has been attained and thus, the progress towards achieving "zero hunger" is on track. Aiming towards becoming a middle-income country, there is hope of declining the poverty rate, but the occurrence of global pandemic intertwined with natural calamities might halt the progress or even might increase the poverty level.

The rest of the goals are either way might be influenced by the high density of population. Based on the current scenario, it is not possible to curtail the number of populations overnight, but indubitably planned distribution is possible. The concentrated areas of very high density of population can further be redistributed by ensuring decentralization of some industries and facilities from the capital and other big cities to rural areas. This might lower the rate of rural to urban migration and will also ensure equal development across the country. Hence, the pressure of population will be to some extent normalized and more attention will be given on the peripheral areas than present. Additionally, circular migration can be promoted countrywide on ad hoc basis when there is shortage of work or labour on seasonal basis.

There are ample opportunities to utilize this huge population by planned actions and effective training programmes. More focus on enlightening the youth with innovative and technological activates is required. These educated and trained manpower then can be employed in various economic activities including entrepreneurship and overseas employment that will expedite the economic development. In addition, policies to provide incentives towards rural area based economic activities will help to reduce the current 
density of population in the major cities. Eventually, this will contribute to regain and maintain environmental sustainability in the long run. Apart from these, policies regarding ensuring wider use of solar energy should be imposed to mitigate energy crisis and tackling climate change issue. Approaches should be changed to minimize groundwater extraction and to rejuvenate river water for domestic use.

Indeed, overpopulation and high population density is a concern, but less attention has been given on outlining how this is affecting the other sectors and might affect the achievement of the targets of the SDGs. This study therefore attempts to draw attention to further investigate this issue and recommend conducting research on detailed and district level study on how the attainment of the SDGs might be influenced by high population density of Bangladesh with proper data and information.

\section{REFERENCES}

A2I (2020). https://a2i.gov.bd/innovation-lab/, Access to Information, accessed on 5 January 2021.

Abedin, J. and Khatun H. (2019). Impacts of Flash Flood on Livelihood and Adaptation Strategies of the Haor Inhabitants: A Study in Tanguar Haor of Sunamganj, Bangladesh. Dhaka University Journal of Earth and Environmental Sciences, 8:41-51.

Abel, G.J., Barakat, B., Samir K.C. and Lutz, W. (2016). Meeting the Sustainable Development Goals leads to lower world population growth. Proceedings of the National Academy of Sciences, 113 (50): 1429414299 , available at 10.1073/pnas.1611386113.

Abusaleh, K. (2017). Demographic dividend in Bangladesh: Quest for initiatives. Society \& Change, XI (3): 37-48.

Ahmad, M.H., Azhar, U., Wasti, S.A., Inam, Z. and Ghani, N. (2005). Interaction between Populations and Environmental Degradation [with Comments]. The Pakistan development review, 44(II):1135-1150.

Akash, M., Akter, J., Tamanna, T. and Kabir, M.R. (2018). The Urbanization and Environmental Challenges in Dhaka City, presented in 7th International RAIS Conference on Social Sciences, available at https://papers.ssrn.com/sol3/papers. cfm?abstract_id $=3152116$.

Al-Zaman, M.S. (2020). Healthcare Crisis in Bangladesh during the COVID-19 Pandemic. The American Journal of Tropical Medicine and Hygiene, 103(4):1357-1359.
Ashraf, M., Ullah, L., Shuvro, M.A. and Salma, U. (2019). Transition from Millennium.

Development Goals (MDGs) to Sustainable Development Goals (SDGs): Blueprint of Bangladesh for Implementing the Sustainable Development Goals (SDGs) 2030. Medicine Today, 31(1): 46-59.

Ayeb-Karlsson, S., van der Geest, K., Ahmed, I., Huq, S. and Warner, K. (2016). A people-centred perspective on climate change, environmental stress, and livelihood resilience in Bangladesh. Sustainability Science, 11(4):679-694.

Bashar, T. and Fung, I.W. (2020). Water Pollution in a Densely Populated Megapolis, Dhaka. Water, 12(8): 21-24.

BBS (2011). Population and Housing Census 2011, Bangladesh Bureau of Statistics, Statistics and Informatics Division, Ministry of Planning, Government of the People's Republic of Bangladesh.

BBS (2015). Bangladesh Disaster-related Statistics 2015: Climate Change and Natural Disaster Perspective, Bangladesh Bureau of Statistics, Statistics and Informatics Division, Ministry of Planning, Government of the People's Republic of Bangladesh.

BBS and UNICEF (2017). A Scoping Analysis of Budget Allocations for Ending Child Marriage in Bangladesh 2017. Bangladesh Bureau of Statistics, Statistics and Informatics Division, Ministry of Planning, Government of the People's Republic of Bangladesh and UNICEF.

BBS (2018). Labour Force Survey 2016-17. Bangladesh Bureau of Statistics, Statistics and Informatics Division, Ministry of Planning, Government of the People's Republic of Bangladesh.

BBS (2019). Report on the Household Income and Expenditure Survey 2016, Bangladesh Bureau of Statistics, Statistics and Informatics Division, Ministry of Planning, Government of the People's Republic of Bangladesh.

BEZA (2021). https://www.beza.gov.bd/economiczones-site/, accessed on 15 February 2021.

BIDS (2016). Skill Gap Analysis for Selected Sectors, BIDS Research Almanac, Skills for Employment Investment Program (SEIP), Finance Division, Ministry of Finance, Government of the People's Republic of Bangladesh.

BIDS (2017). Labour Market and Skill Gap in Bangladesh, BIDS Study Report, Skills for Employment Investment Program (SEIP), Finance Division, Ministry of Finance, Government of the People's Republic of Bangladesh. 
Buchmann, N., Field, E., Glennerster, R., Nazneen, S., Pimkina, S. and Sen, I. (2017). Power vs money: Alternative approaches to reducing child marriage in Bangladesh, a randomized control trial, unpublished manuscript, available at https:// www.povertyactionlab.org/ sites/default/files/researchpaper/Power-vs-Money-Working-Paper.pdf, accessed on 10 February 2021.

Chatterjee, R., Atta-ur-Rahman; Tran, T., Shaw, R. (2016). Urban Food Security in Asia: A Growing Threat, in Rajib Shaw, Atta-ur-Rahman, Akhilesh Surjan and Gulsan Ara Parvin edited Urban Disasters and Resilience in Asia; Elsevier Inc.: ButterworthHeinemann, UK, 161-178.

Chowdhury, M.N.M. and Hossain, M. (2018). Population growth and economic development in Bangladesh: Revisited Malthus. arXiv preprint arXiv:1812.09393.

Daily Star (2021). Getting a shot at a new life, The Daily Star, available at https://www.thedailystar.net/ back page/ news/ gettingshot- new- life- 2039941 accessed on 6 February 2021.

Databd (2020). https://databd.co/profiles/ economy/ profile-the-megaprojects-in-bangladesh, accessed on 5 January 2021.

DGHS (2012). Health Bulletin, 2012, Directorate General of Health Services, Ministry of Health and Family Welfare, Government of the People's Republic of Bangladesh, available at https://dghs.gov.bd/bn/licts_file/images/Health_Bulleti $\mathrm{n} /$ HealthBulletin2012_full.pdf, accessed on 11 December 2020.

DGHS (2020). Health Bulletin, 2019, Directorate General of Health Services, Ministry of Health and Family Welfare, Government of the People's Republic of Bangladesh, available at https://dghs.gov.bd/ images/docs/Publications/Health\%20Bulletin \% 202019\%20Print\%20Version\%20(2)-Final.pdf, accessed on 11 December 2020.

Dhaka Tribune (2020). Bangladesh once again top contributor of troops to UN peacekeeping missions, Dhaka Tribune, available at https://www. dhakatribune. com/ bangladesh/ foreign-affairs/ 2020/09/12/ bangladesh-is-largest-contributor-of-troops-to-unpeacekeeping-missions, accessed on 14 January 2021.

Financial Express (2020). Demographic Dividend: A Roadmap to progress, The Financial Express, available at https:// www.thefinancialexpress.com. bd/ views/ reviews/ demographic- dividend-a- roadmap-toprogress-1600268169, accessed on 5 January, 2021.

GED (2020a). $8^{\text {th }}$ Five Year Plan FY 2021-FY2025 (Final draft), General Economic Division, Bangladesh
Planning Commission, Ministry of Planning, Government of the People's Republic of Bangladesh.

GED (2020b). Sustainable development Goals: Bangladesh Progress Report 2020, General Economic Division, Bangladesh Planning Commission, Ministry of Planning, Government of the People's Republic of Bangladesh.

Hák, T., Janoušková, S. and Moldan, B. (2016). Sustainable Development Goals: A need for relevant indicators. Ecological Indicators, 60: 565-573.

Hakeem, M.A. (2017). Effect of population density on the level of development, available at https://mpra.ub.uni-muenchen.de/82301/ accessed on 5 January 2021.

Hasan, M. K., Shahriar, A., and Jim, K. U. (2019). Water pollution in Bangladesh and its impact on public health. Heliyon, 5(8), available at https://doi.org/10.1016/j.heliyon.2019.e02145, accessed on 1 February 2021.

Hasan, M.N., Hossain, M.S., Bari, M.A. and Islam, M.R. (2013). Agricultural land availability in Bangladesh. SRDI, Dhaka, Bangladesh, 42, available at https:// d1wqtxts1xzle7.cloudfront.net/37099598/ Agricultural-land-availability-in-Bangladesh-withcover-page.pdf.

Hasnath, S.A. (2020). Uneven Development in Bangladesh: A Temporal and Regional Analysis, in Zhenhua Chen, William M. Bowen and Dale Whittington eds. Development Studies in Regional Science, Springer, Singapore, 199-219.

Hayes, G.R. and Jones, G. (2015). The Impact of Demographic Transition on Socio-economic Development in Bangladesh: Future Prospects and Implications for Public Policy, United Nations Population Fund, Bangladesh Country Office.

Hossain M. I. (2021). COVID-19 Impacts on Employment and Livelihood of Marginal People in Bangladesh: Lessons Learned and Way Forward, South Asian Survey, 28 (1) : 57-71. doi:

$10.1177 / 0971523121995072$.

Islam, R. and Jahangir, A. R. (2020). Corona fallout spells disaster for millions of poor Bangladeshis: Economists. United News of Bangladesh, available at https://unb.com. bd/category/special/corona-falloutspells-disaster-for-millions-of-poor- bangladeshiseconomists/48533.

Islam, N. and Nazem, N.I. (2017). National Atlas of Bangladesh, Asiatic Society of Bangladesh.

Karim, A.R., Uddin, M.N., Rana, M., Khandaker, M.U., Faruque, M.R.I. and Parvez, S.M. (2020). Modeling on population growth and its adaptation: A comparative analysis between Bangladesh and India. 
Journal of Applied and Natural Science, 12(4): 688701.

Katekar V.P., Deshmukh S.S., and Elsheikh A.H. (2020). Assessment and Way Forward for Bangladesh on SDG-7: Affordable and Clean Energy, International Energy Journal, 3A: 421 - 438.

Khatun, F. (2000). Population and Environment in Bangladesh: Designing a Policy Accounting for Linkages, available at https://www.researchgate.net/ publication/ 242740467, accessed on 15 February, 2021.

Khatun H. (2020). Population Density and Vulnerability: A Challenge for Sustainable Development in Bangladesh. Submitted and presented in Population Expert Committee meeting on 21 December 2020, Planning Commission, Government of Bangladesh.

Khatun, H., Kabir H. and Nahar L. (2021). Outmigration as Survival Strategy for Char Dwellers in Bangladesh: Case Studies of Three Major Riverine Chars, in Mohammad Zaman and Mustafa Alam (eds.), Life on the Edge: Toward an Inclusive and Integrated Char Development in Bangladesh. Springer, (In press).

Khuda, B.E. (2011). "Social Safety Net Programmes in Bangladesh: A Review," Bangladesh Development Studies, Bangladesh Institute of Development Studies (BIDS), 34(2): 87-108.

Kopnina, H. and Washington, H. (2016). Discussing Why Population Growth is Still Ignored or Denied, Chinese Journal of Population Resources and Environment, 14(2):133-143, doi: 10.1080/

10042857.2016.1149296.

Macrotrends (2020). https://www.macrotrends.net/ countries/BGD/bangladesh/population-

density\#: :text=United\%20Nations\%20projections $\% 2$ 0are $\% 20$ also, $\mathrm{a} \% 201.03 \% 25$

$\% 20$ increase $\% 20$ from $\% 202018$, accessed on 5

December 2020.

Majumdar, S. and Dey, S. (2020). Socio-economic and Demographic Determinants of Women Participation in Labour Force in Rural Bangladesh, Journal of Asiatic Society of Bangladesh Science, 46(1): 103-115.

MoF (2020). Medium Term Macroeconomic Policy Statement 2020-21 to 2022- 23. Medium Term Macroeconomic Policy Statement (MTMPS). Macroeconomic Wing, Finance Division, Ministry of Finance, Government of People's Republic of Bangladesh.

MoFA (2018). Climate Change Profile Bangladesh, Ministry of Foreign Affairs, Government of the People's Republic of Bangladesh, available at https://reliefweb.int/report/bangladesh/climate changeprofile-bangladesh, accessed on 11 December 2020.

Mondal, M. S. H. (2019). The implications of population growth and climate change on sustainable development in Bangladesh. Jàmbá: Journal of Disaster Risk Studies, 11(1):1-10.

MoYS (2017). National Youth Policy 2017. Ministry of Youth and Sports, Government of People's Republic of Bangladesh (GoB).

Nazem, N.I. (2018). Planning Landuse for Sustainable Development in Bangladesh, in Hafiza Khatun, Nasreen Ahmad, A. Q. M. Mahbub and Humayun Kabir edited, Environment and Sustainable Development in Bangladesh: Geographical Perspectives, Department of Geography and Environment, University of Dhaka.

Population centre (2021). https://

www.populationmedia. org/ issues- world-populationgrowth, accessed on 5 March 2021.

PPPO (2021). https://www.pppo.gov.bd/projects.php, accessed on 5 January 2021.

Prodhan, A.S.U. and Kaeser, A. (2019). Municipal Solid Waste Management in Dhaka City: Present Status, Problems, and Probable Solutions-A Review, available at https:// www.researchgate.net/ publication/ 340581725_Municipal_Solid_Waste_Management_in Dhaka_City_Present_Status_Problems_and_Probable Solutions, accessed on 15 January 2021.

Rakib, M. R., Islam, M. N., Parvin, H. and Amstel, A.V. (2018). Climate Change Impacts form the Global Scale to the Regional Scale: Bangladesh, in Md. Nazrul Islam and Andre van Amstel edited, Bangladesh I: Climate Change Impacts, Mitigation and Adaptation in Developing Countries, Springer.

Reza, S. (2021). Domestic Violence against Women in the Time of Pandemic in Bangladesh, IOSR Journal of Humanities and Social Science, 26(1):44-53, DOI: 10.9790/0837-2601054453.

Riaz, A. (2020). Bangladesh's COVID-19 stimulus: Leaving the most vulnerable behind. Atlantic Council. https://www.atlanticcouncil.org/blogs/new atlanticist/bangladeshs-covid-19-stimulus-leaving-themost-vulnerable-behind/.

Roy, D., Sarker Dev, D. and Sheheli, S. (2019). Food security in Bangladesh: insight from available literature, Journal of Nutrition and Food Security, 4(1): 66-75.

Sachs, J.D. (2012). From millennium development goals to sustainable development goals. The lancet, 379(9832): 2206-2211. 
Salahuddin, M., Khatun, R. and Bilkis, S. (2014). Present Situation of Female Education in Bangladesh: A Comparative Analysis of Last Decade, BPDM Journal of Research, 1(2), available at SSRN: https://ssrn.com/abstract $=3372022$

Sarkar, A. M., Rahman, A. K. M. L., Samad, A., Bhowmick, A. C. and Islam, J. B. (2019). Surface and Ground Water Pollution in Bangladesh: A Review. Asian Review of Environmental and Earth Sciences, 6(1): 47-69, available at https://doi.org/10.20448/ journal.506.2019.61.47.69 accessed on 5 February, 2021.

Siddiqui, M.R. and Hossain, M.A. (2020). Climate Change and Migration in Coastal Areas in South Asia. Climate Action, 132-143.

Siddiqy, M.R. (2017). Urban environment and major challenges in sustainable development: Experience from Dhaka City in Bangladesh. South East Asia Journal of Public Health, 7(1): 12-16.

Sobhan, R. (2017). Bangladesh's Permanent Liberation Struggle: Constructing an Inclusive Democratic Society, available at https://cpd.org.bd/wpcontent/uploads/2018/08/Bangladesh\%E2\%80\%99sPermanent-Liberation-Struggle-Professor-RehmanSobhan.pdf., accessed on 15 February 2021.

Stafford-Smith, M., Griggs, D., Gaffney, O., Ullah, F., Reyers, B., Kanie, N., Stigson, B., Shrivastava, P., Leach, M. and Connell, D.O'. (2017). Integration: the key to implementing the Sustainable Development Goals. Sustainability Science, 12: 911-919, available at https://doi.org/10.1007/s11625-016-0383-3, accessed on 5 February 2021.

Statista (2020). https://www.statista.com/statistics/ 64683/top-fifty-countries-with-the- highest-populationdensity/, accessed on 5 December 2020.

Sumiya, N.N. and Khatun, H. (2016). Groundwater variability in Bangladesh: assessment based on rainfall variation and use of water in irrigation. Journal of the Asiatic Society of Bangladesh, Science, 42(2):177-189.

Sumiya, N. N.; Ali, A.A.B. and Kabir, M.H. (2019). Flash Floods in the Northeastern Bangladesh: Looking Back-Moving Forward, in Hafiza Khatun, Abdul Baqee and Humayun Kabir edited People at Risk: Disaster and Despair, Disaster Research Training and Management Centre (DRTMC), Dhaka, 211-230.

Swain R.B. (2018). A Critical Analysis of the Sustainable Development Goals, in Leal Filho W. edited Handbook of Sustainability Science and Research. World Sustainability Series. Springer, Cham. https://doi.org/10.1007/978-3-319-63007-6_

Swapan, M.S.H.; Zaman, A.U.; Ahsan, T.; Ahmed, F. (2017). Transforming Urban Dichotomies and
Challenges of South Asian Megacities: Rethinking Sustainable Growth of Dhaka, Bangladesh. Urban Science, 1 (31), available at https://doi.org/10.3390/urbansci104003, accessed on 15 February 2021.

Titumir, R. A. M. (2021). Numbers and Narratives in Bangladesh's Economic Development, Springer Books, Springer, number 978-981-16-0658-8, June.

United Nations, Department of Economic and Social Affairs, Population Division (2019). World Urbanization Prospects: The 2018 Revision (ST/ESA/SER.A/420). New York: United Nations available at https://population.un.org/wup/ Publications/Files/WUP2018-Report.pdf, accessed on 1 January, 2021.

UNDP (2020). https://www.undp.org/content/undp/en/ home/sdgoverview/mdg goals.html, accessed on 28 December 2020.

UNFPA (2013). Sustainable Development and Population Dynamics: Placing People at the Centre, available at https://www.unfpa.org/press/sustainableevelopment-and- population-dynamics-placing-peoplecentre.

UNFPA (2014). The power of 1.8 billion: Adolescents, Youth and the Transformation of Future, Publication and Web integrative design and production, UNFPA State of the World Population 2014, available at https://www.unfpa.org/sites/default/files/pub- pdf/ENSWOP14-Report_FINAL-web.pdf accessed on 10 January 2021.

UNFPA (2015). The Impact of the Demographic Transition on Socioeconomic Development in Bangladesh: Future Prospects and Implications for Public Policy, United Nations Population Fund, Bangladesh, available at https://www.researchgate.net/publication/309464554 The_Impact_of

Demographic_Transition_on_Socioeconomic_Develop ment of Bangladesh_Future_Prospects and Implicati ons_for_Public_Policy, accessed on 1 December, 2020.

UNFPA (2016). Urbanization and Migration in Bangladesh, United Nations Population Fund, Bangladesh, available at https:// bangladesh.unfpa.org/en/ publications/urbanizationand-migration-bangladesh, accessed on 1 December, 2020 .

UNFPA (2020). Demographic Dividend, available at https://bangladesh.unfpa.org/en/topics/demographicdividend-1, accessed on 1 January 2021.

UNICEF (2020). available at https://data.unicef.org/resources/ data_explorer/unicef_f/?ag=UNICEF\&df=GLOBAL DATAFLOW\&ver $=1.0 \& d q=B G D . C M E \_M R M 0 . \& s t a r$ 
tPeriod=1970\&endPeriod=2020, Accessed on 1 December 2020.

Van Bavel, J. (2013). The world population explosion: causes, backgrounds and projections for the future. Facts, views \& vision in ObGyn, 5(4): 281.

Walker, R. (2015). How to meet the challenges posed by population growth, available in https://www.devex.com/news/how-to-meet-thechallenges-posed-by-population- growth-86377, accessed on 5 March, 2021.

World Bank (2020).

https://data.worldbank.org/indicator/ SP.URB. TOTL.IN. ZS? locations $=\mathrm{BD}$, accessed on 6 December 2020.
Worldometer (2020). www.worldometer.com, accessed on 1 December 2020.

Worldometer (2021).

https:/www.worldometers.info/world-population, accessed on 5 March 2021.

Zaman, R. U. and Biswas, N. R. (2017). Bangladesh and United Nations Peacekeeping Missions: The Quest for A National Policy to Meet the Challenge of Uncertainty, Journal of the Asiatic Society of Bangladesh (Humanities), 62(2):155-181.

Zaman, M. and Khatun, H. (2019). Developmentinduced Displacement and Resettlement in Bangladesh: Case Studies and Practices. Nova Science Publishers, Incorporated. 
